\title{
Sea Turtles as Potential Dispersal Vectors for Non-indigenous Species: The Veined Rapa Whelk as an Epibiont of Loggerhead Sea Turtles
}

JM Harding

Virginia Institute of Marine Science

WJ Walton

CM Trapani

MJ Frick

Roger L. Mann

Virginia Institute of Marine Science

Follow this and additional works at: https://scholarworks.wm.edu/vimsarticles

Part of the Aquaculture and Fisheries Commons, and the Marine Biology Commons

\section{Recommended Citation}

Harding, JM; Walton, WJ; Trapani, CM; Frick, MJ; and Mann, Roger L., Sea Turtles as Potential Dispersal Vectors for Non-indigenous Species: The Veined Rapa Whelk as an Epibiont of Loggerhead Sea Turtles (2011). Southeastern Naturalist, 10(2), 233-244.

doi: $10.1656 / 058.010 .0204$

This Article is brought to you for free and open access by the Virginia Institute of Marine Science at W\&M ScholarWorks. It has been accepted for inclusion in VIMS Articles by an authorized administrator of W\&M ScholarWorks. For more information, please contact scholarworks@wm.edu. 


\title{
Sea Turtles as Potential Dispersal Vectors for Non-indigenous Species: The Veined Rapa Whelk as an Epibiont of Loggerhead Sea Turtles
}

\author{
Juliana M. Harding ${ }^{1,2, *}$, Wendy J. Walton ${ }^{3}$, Christina M.Trapani ${ }^{3}$, \\ Michael G. Frick ${ }^{4}$, and Roger Mann ${ }^{1}$
}

\begin{abstract}
We present the first record of Rapana venosa (Veined Rapa Whelk) as an epibiont of Caretta caretta (Loggerhead Sea Turtle) and the first observation of rapa whelks in the South Atlantic Bight, USA. Veined Rapa Whelks are invasive shellfish predators. The only known North American population of Veined Rapa Whelks is in the southern Chesapeake Bay. Collections of Veined Rapa Whelks as epibionts on Loggerhead Sea Turtles from Norfolk, VA and Wassaw Island, GA present a previously undescribed vector for whelk range expansion to widely separated coastal habitats. In October 2008, a live juvenile Loggerhead stranded near Norfolk, VA with a Veined Rapa Whelk attached to its carapace. Since May 2005, a total of eight Loggerheads with Veined Rapa Whelks as epibionts have been observed nesting on Wassaw Island, GA. The shell lengths of the two smallest Wassaw Island whelks (1.9 and $2.6 \mathrm{~mm}$ ) indicate that the whelks settled from the plankton $24-48 \mathrm{hr}$ immediately prior to collection in Georgia. This time frame is not commensurate with turtle migration from Chesapeake Bay to Wassaw Island and indicates a whelk source that is geographically distinct from the Chesapeake Bay. Rapa whelk use of Loggerhead carapaces as settlement and juvenile habitat is of serious concern given the observed potential for coastal and oceanic migrations by turtles to facilitate Veined Rapa Whelk dispersal.
\end{abstract}

\section{Introduction}

The Chesapeake Bay is one of the most important foraging areas for immature and adult Caretta caretta L. (Loggerhead Sea Turtle) in the southeastern US, and current estimates indicate that approximately 3500 sea turtles migrate annually into the Chesapeake Bay to forage (Mansfield 2006, Musick and Limpus 1997, Seney and Musick 2007). Additionally, the southeastern US coast from Virginia to western Florida represents one of the largest Loggerhead Turtle rookeries in the world, with over 60,000 nests deposited annually (NMFS and USFWS 2008). Because female Loggerhead turtles consume few, if any, prey in between multiple nesting events during a reproductive season (up to eight nests deposited every two weeks from May-August), post-nesting Loggerheads travel great distances on extended foraging bouts in order to replenish depleted energy reserves (Dodd 1988, Meylan et al. 1983, Plotkin and Spotila 2002, Williams and Frick 2008). For instance,

\footnotetext{
${ }^{1}$ Department of Fisheries Science, Virginia Institute of Marine Science, College of William and Mary, Gloucester Point, VA 23062. ${ }^{2}$ Current address - Department of Marine Science, Coastal Carolina University, PO Box 261954 Conway, SC 29528. ${ }^{3}$ Virginia Aquarium and Marine Science Center, 717 General Booth Boulevard, Virginia Beach, VA 23451. ${ }^{4}$ Friends of the National Zoo, Smithsonian National Zoological Park, Washington, DC 20008. "Corresponding author - jharding@coastal.edu.
} 
post-nesting Loggerheads from Wassaw Island, GA are documented to travel to foraging grounds as far north as Long Island Sound, NY and as far west as Mobile, AL, but foraging bouts that extend to the Chesapeake and Delaware Bay regions appear to be most common (Plotkin and Spotila 2002, Williams and Frick 2008).

A number of studies have investigated the plants and animals that live upon sea turtles (epibionts) in the southeastern US, particularly those from nesting Loggerheads (for reviews, see Frick et al. 2003, Pfaller et al. 2008). Many of the epibiotic species that occur on Loggerheads are obligate commensals. However, most can also be found living upon most submerged substrata, and their occurrence on Loggerheads appears to be largely incidental (Frick et al. 2010). In Georgia and Florida, gastropod molluscs are common epibionts of Loggerheads - including relatively large snails of the family Muricidae (Frazier et al. 1985, Pfaller et al. 2008). The muricids reported thus far from Loggerheads are species native to the southeastern US (Stramonita haemastoma floridana Conrad [Southern Oyster Drill] and Chicoreus pomum Gmelin [Apple Murex]). The present study, however, is the first report of the invasive muricid Rapana venosa Valenciennes, (Veined Rapa Whelk) as epibionts of Loggerheads (nesting turtles in Georgia and foraging turtles in the Chesapeake Bay).

Veined Rapa Whelks are generalist shellfish predators whose prey size and diversity changes ontogenetically, whereby small whelks $(<50-70 \mathrm{~mm}$ shell length) consume barnacles and small Crassostrea virginica Gmelin (Eastern Oyster) and Mercenaria mercenaria L. (Northern Quahog) (Harding et al. 2007a), and larger whelks consume larger Oysters and Quahogs (Savini et al. 2002). Habitat preferences may also change with ontogeny, with smaller whelks occupying hard substrates as epifauna (Harding 2003), and larger whelks spending some portion of their lives as infauna burrowed in sand or mud substrate (Bombace et al. 1994, Harding and Mann 1999). Rapana venosa displays high annual fecundity (Harding et al. 2007b, 2008) and rapid progression from a planktonic larval stage (Chung et al. 1993, Harding 2006) through benthic juvenile, with generation times of $<1$ year in Chesapeake Bay (J. Harding, unpubl. data). These life-history characters facilitate rapid colonization by Rapa Whelks in new regions (Harding et al. 2008, Mann et al. 2004, Sakai et al. 2001).

These whelks originated in the estuarine and marine habitats of Asia, and were subsequently introduced into the Black and Mediterranean Seas (Mann et al. 2004). In 1998, R. venosa was first reported from the Chesapeake Bay (Harding and Mann 1999, Mann and Harding 2000). Invasive populations of rapa whelks have also been reported from the Rio de la Plata Argentina-Uruguay in South America (Giberto et al. 2006, Pastorino et al. 2000), and from the North Sea (Vink et al. 2005). The population of rapa whelks from the lower Chesapeake Bay, VA (Harding and Mann 1999, 2005), is the only known population of rapa whelks in North America.

Drastic declines in populations of Black Sea shellfish fishery species (e.g., Ostrea edulis L. [Common European Oyster] and Mytilus galloprovincialis Lamarck [Mediterranean Blue Mussel]) have been documented since the introduction of rapa whelks to the Black Sea in the mid-1940s (Chukchin 1984, Drapkin 1963, Mann et 
al. 2004) and subsequent expansion of the established populations numerically and spatially. Through the introduction of a novel shellfish predator into the Chesapeake Bay, there is the possibility that a similar scenario might exist for ecologically and economically important shellfish species in the eastern US (i.e., Crassostrea virginica and Mercenaria mercenaria) (Harding and Mann 1999, 2005).

The present study is of particular interest, not only because it includes the first observations of Veined Rapa Whelks as epibionts of Loggerhead Turtles, but it also presents the first report of this invasive, and potentially detrimental (ecologically and economically) species outside of the Chesapeake Bay. Moreover, our observations strongly suggest that, in addition to human-facilitated transport (e.g., via ship traffic), rapa whelks may enjoy increased dispersal opportunities through their association with Loggerhead Turtles - a federally threatened species that is documented to travel to widely separated regions in the US with locally valuable shellfish stocks.

\section{Methods}

\section{Chesapeake Bay, VA}

On 29 October 2008, a live juvenile Loggerhead Turtle stranded on a Chesapeake Bay beach in Willoughby Bay, Norfolk, VA $\left(36.9495^{\circ} \mathrm{N}, 76.2702^{\circ} \mathrm{W}\right.$; Fig. 1) and was rescued at 1330 EST while the tide was ebbing. The turtle was transported live to the Marine Animal Care Center of the Virginia Aquarium and Marine Science Center for examination and rehabilitation. The carapace was examined for the presence of living epibionts, and the presence of epibiotic species identified to taxon was noted. A single Veined Rapa Whelk was observed attached to the right posterior quadrant of the carapace and was removed.

Average daily air temperature data for October 2008 were obtained from a Virginia Institute of Marine Science (VIMS) monitoring station near the stranding site (Middle Ground Light, James River; Fig. 1). Average daily air temperature and water temperature data from a monitoring site at VIMS (Gloucester Point, York River; Fig. 1) were compared to the Middle Ground Light air temperature data and used to estimate water temperature at the stranding site. In general, average daily air temperatures recorded at Middle Ground Light and at VIMS during October 2008 followed similar trends and were within $1{ }^{\circ} \mathrm{C}$ of each other. The depth of the VIMS water temperature monitoring station is similar to the depth in Willoughby Bay adjacent to the stranding site $(3 \mathrm{~m})$.

\section{Wassaw Island, GA}

Wassaw Island is part of the Wassaw National Wildlife Refuge located near Savannah, GA (Fig. 1). A long-term Loggerhead Turtle saturation tagging project began on Wassaw Island in 1973 and continues to the present (see Williams and Frick 2008 for methodologies). Since 1997, comprehensive examinations of the epibionts of nesting Loggerheads at Wassaw Island have been conducted (see Frick et al. 1998 for methodologies). Average weekly water temperatures for coastal waters adjacent to Wassaw Island, GA were calculated from sea-surface temperature data obtained for the NOAA monitoring site at Fort Pulaski in Savannah Harbor $\left(32.033^{\circ} \mathrm{N}, 80.902^{\circ} \mathrm{W}\right.$ : FPKG1, 2005-2009). 


\section{Results and Discussion}

Loggerhead Turtles typically inhabit the Chesapeake Bay from May to November when water temperatures are above $18^{\circ} \mathrm{C}$ (Keinath et al. 1987, Lutcavage and Musick 1985, Mansfield et al. 2002). The juvenile Loggerhead turtle observed in Norfolk, VA was $62.2 \mathrm{~cm}$ long (curved carapace length [CCL]; Fig. 2A) and weighed $28 \mathrm{~kg}$. The turtle appeared thin and lethargic with a core body temperature of $11.6{ }^{\circ} \mathrm{C}$. These symptoms are consistent with cold stunning (Burke et al. 1991), a severe hypothermic condition associated with sea turtles when water temperatures drop quickly. Air temperature in Willoughby Bay at the stranding site on the afternoon of 29 October 2008 was $8-9^{\circ} \mathrm{C}$, with an estimated water temperature of $15-15.5^{\circ} \mathrm{C}$. Air and water temperature rapidly decreased from 25 through 29 October, and by 29 October, the air temperature was more than $10{ }^{\circ} \mathrm{C}$ lower than that observed on 25 October. Water temperature declined approximately $2{ }^{\circ} \mathrm{C}$ during the same period. The turtle was maintained at a water temperature of $25.5^{\circ} \mathrm{C}$ through successful rehabilitation resulting in its release from North Carolina in the spring of 2009.

Epibiotic fauna identified on the juvenile Loggerhead's carapace included Platylepas hexastylos Fabricius and Chelonibia testudinaria L. (barnacles), Crepidula fornicata L. (Atlantic Slippersnail), Caprella andrea Mayer (an amphipod), unidentified algae (Fig. 2B), and a single Veined Rapa Whelk (Fig. 2C).

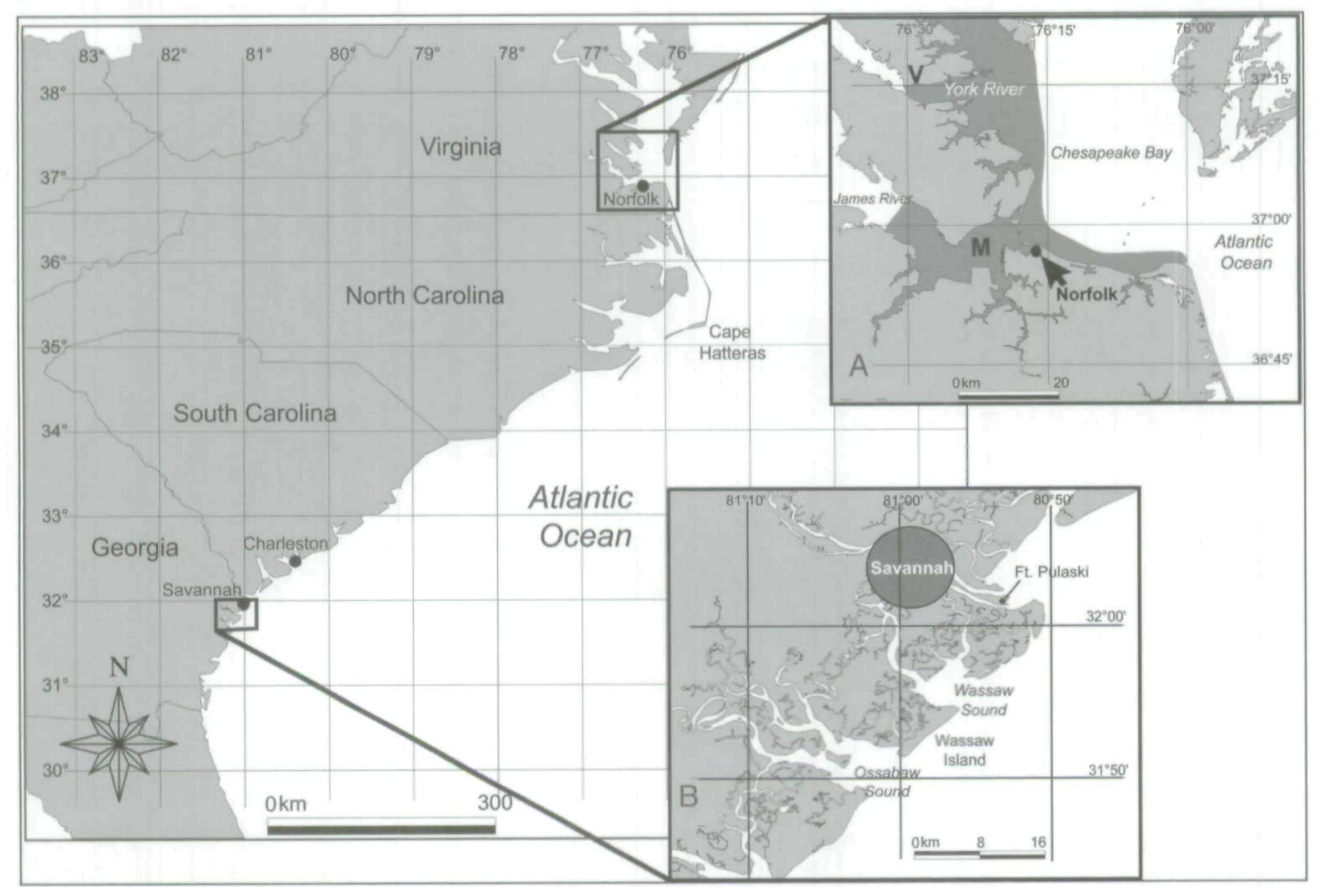

Figure 1. Map of the US Atlantic coast with: A. the known range of Veined Rapa Whelks in Chesapeake Bay (grey), the site of the Loggerhead Turtle stranding (black arrow), and stations for which air $(\mathrm{M}=$ Middle Ground Light $)$ and air and water temperature $(\mathrm{V}=$ Virginia Institute of Marine Science) were recorded during October 2008; and B. Wassaw Island, GA in relation to Savannah, GA and Ft. Pulaski, where sea surface temperature was recorded from 2005-2009. 
The rapa whelk measured $62.7 \mathrm{~mm}$ shell length and $42.3 \mathrm{~mm}$ shell shoulder width (Fig. 2C). In Chesapeake Bay, shell lengths of $\approx 60 \mathrm{~mm}$ correspond to adult rapa whelks that are 1-2 yr old (J. Harding, unpubl. data). Loggerhead Turtles host over 125 epibiotic species worldwide (Frick et al. 2003), including numerous gastropods (Frazier et al. 1985, Pfaller et al. 2008), and the presence of epibiota on a sea turtle carapace is not unusual or always indicative of poor health (Stamper et al. 2005). The posterior quadrants, where the Veined Rapa Whelk was observed, are among the most prevalent sites for epibiota attachment on Loggerheads (Frick et al. 1998). No carapace damage was observed at the whelk's location after it was removed (Fig. 2D). The Loggerhead Turtle stranding location is within the known distribution of Veined Rapa Whelks in the Chesapeake Bay (Harding and Mann 2005; Fig. 1).

Loggerhead Turtles nest on Wassaw Island, GA from May through August each year (Williams and Frick 2008), and 12 Veined Rapa Whelks were collected as epibionts on eight nesting turtles from 2005 through 2009 (Table 1). Nesting host Loggerheads ranged from 93-118 cm CCL (Table 1) and all appeared healthy. Whelks were observed in proximity to other epibiotic fauna that could serve as potential prey items (Table 1), including Ostrea equestris Say (Horse Oyster), Anadara ovalis Bruguiere (Blood Ark), and Chelonibia testudinaria L. (non-stalked barnacle). Smaller rapa whelks were typically found near fauna that increased carapace heterogenity and offered potential shelter for whelks.

Ours are the first observations of Veined Rapa Whelks as epibionts of Loggerhead Turtles and the first for any sea turtle in North American waters. Lezama et al. (2006) documented the presence of rapa whelks on Chelonia mydas L. (Green

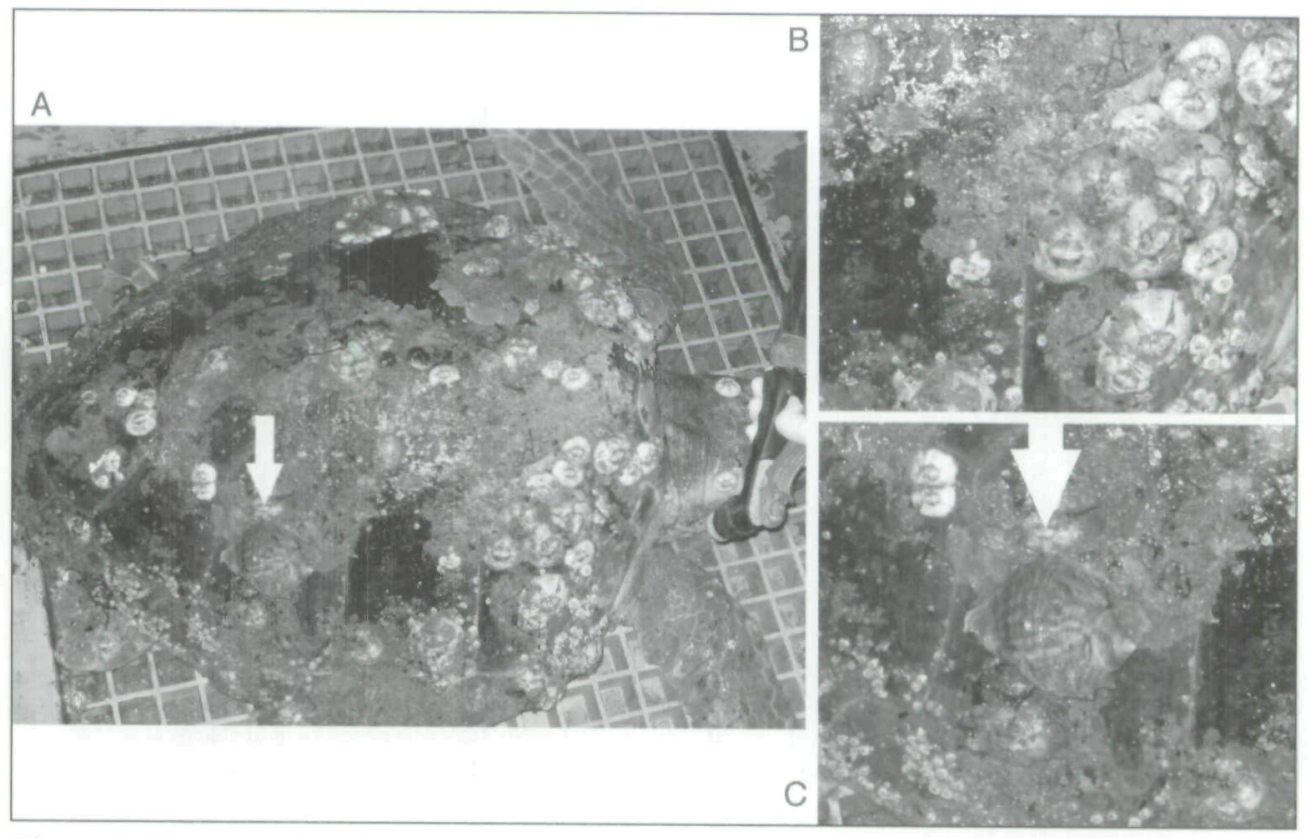

Figure 2. Photographs of A. the juvenile Loggerhead Turtle, B. close-up of the turtle carapace, and C. close-up of the posterior right quadrant of the carapace with the Veined Rapa Whelk. The arrows note the approximate position of the Rapa Whelk. 
Sea Turtle), in the coastal waters of the Rio de la Plata estuary, Uruguay from 17-28 May 2005. Host Green Turtles ranged in size from 37 to $63.5 \mathrm{~cm}$ CCL. These host turtles were stationary and had either stranded or been entangled in coastal gill nets at the time of discovery (Lezama et al. 2006). The number of rapa whelks on these turtles ranged from 2 to 49 whelks per turtle, with an average shell length of $70.6 \mathrm{~mm} \pm 6 \mathrm{~mm}$. Lezama et al. (2006) did not characterize the epibiotic communities of the Green Turtles hosting rapa whelks, and there are no corresponding water temperature data. Using the water temperature data provided by Jaureguizar et al. (2003) for the Rio de la Plata as a general guide, water temperatures in May 2005 would likely have been in transition from warm summer conditions $\left(10-18\right.$ February $\left.1996=21{ }^{\circ} \mathrm{C}\right)$ to cooler fall/winter conditions (29 June-5 July $1996=10^{\circ} \mathrm{C}$ ). It is possible that temperature stress was a factor in the Green Turtle-rapa whelk associations described by Lezama et al. (2006). Rapa whelks may have incidentally encountered stationary turtles (stranded or trapped in gill nets) while foraging for food in the surrounding waters.

The Chesapeake observation likely corresponds to a rapa whelk scavenging on epibiota attached to the carapace of a stranded turtle. The collection of epibionts on the carapace of the Loggerhead Turtle stranded in the Chesapeake Bay may have attracted the rapa whelk to the stationary turtle. Rapana spp. are known as bivalve predators (e.g., Chukchin 1984, Harding and Mann 1999, Savini et al. 2002, Zolotarev 1996). However, Rapana bezoar L. (Bezoar Rapa Whelk), a rapa whelk from Hong Kong, is a documented scavenger or carrion feeder (Morton 1994). Given the debilitated condition of the juvenile Loggerhead from the Chesapeake Bay, and the initial stages of necrosis commonly associated with such turtles (Norton et al. 2008), it is possible that bacterial chemical cues also attracted $R$. venosa to scavenge upon the stranded host turtle. Such is also a likely scenario for some of the turtles examined by Lezama et al. (2006).

The Wassaw Island observations correspond to use of the turtle carapace as a settlement and foraging habitat by juvenile Veined Rapa Whelks. This interaction, whereby the epibiont community on the turtle carapace acts essentially as a

Table 1: Description of turtles, whelks, and epibionts that would be potential whelk prey from Norfolk, VA and Wassaw Island, GA. WOY = week of the year. CCL $=$ Loggerhead curved carapace length $(\mathrm{cm}) . \mathrm{SL}=$ Whelk shell length $(\mathrm{mm})$.

\begin{tabular}{|c|c|c|c|c|}
\hline Location & $\begin{array}{c}\text { Observation } \\
\text { date }\end{array}$ & CCL & SL & Epibiont prey field \\
\hline Norfolk, VA & $10 / 29 / 2008$ & 62.2 & 62.7 & $\begin{array}{l}\text { Platylepas hexastylos, Chelonibia } \\
\text { testudinaria }\end{array}$ \\
\hline \multirow[t]{8}{*}{ Wassaw Island, GA } & $\begin{array}{l}5 / 5 / 2005 \\
6 / 30 / 2005\end{array}$ & 102.0 & $15.1,15.7$ & Chelonibia testudinaria, Ostrea equestris \\
\hline & $6 / 30 / 2005$ & 98.0 & 14.9 & Chelonibia testudinaria, Sphenia antillensis \\
\hline & $6 / 15 / 2006$ & 118.0 & $2.6,24.7$ & Chelonibia testudinaria, Anadara ovalis \\
\hline & $7 / 12 / 2007$ & 101.0 & 22.0 & Chelonibia testudinaria, Ostrea equestris \\
\hline & $7 / 25 / 2008$ & 99.5 & $1.9,29.8$ & Chelonibia testudinaria, Sphenia antillensis \\
\hline & $8 / 2 / 2008$ & 112.3 & 17.2 & Chelonibia testudinaria, Ostrea equestris \\
\hline & $5 / 31 / 2009$ & 93.5 & $12.0,13.4$ & Anadara ovalis, Sphenia antillensis \\
\hline & $7 / 7 / 2009$ & 106.0 & 15.8 & \\
\hline
\end{tabular}


mobile hard substrate to where Veined Rapa Whelk veligers successfully recruit, presents a dispersal vector for whelks that has not previously been considered. Turtles breathing at the surface swim through the photic zone, presenting a settlement substrate in proximity to metamorphosing whelk veligers. Rapa whelk veligers settle from the plankton at shell lengths (SL) of 1.18-1.24 mm at water temperatures above $20{ }^{\circ} \mathrm{C}$ (Harding 2006). Figure 3 presents a growth curve for Veined Rapa Whelks cultured in flow-through conditions at water temperatures above $20^{\circ} \mathrm{C}$ from hatching to settlement, and through the first 60 days post settlement (J. Harding, unpubl. data). These data demonstrate that the growth of post-settlement juvenile whelks is rapid, with whelks reaching a SL of $30 \mathrm{~mm}$ within 60 days. Regional water temperatures at Wassaw Island when nesting turtles were observed were in excess of $20^{\circ} \mathrm{C}$ (Fig. 4). The two smallest whelks collected at Wassaw Island (1.9 and $2.6 \mathrm{~mm} \mathrm{SL}$, Table 1) are within the expected

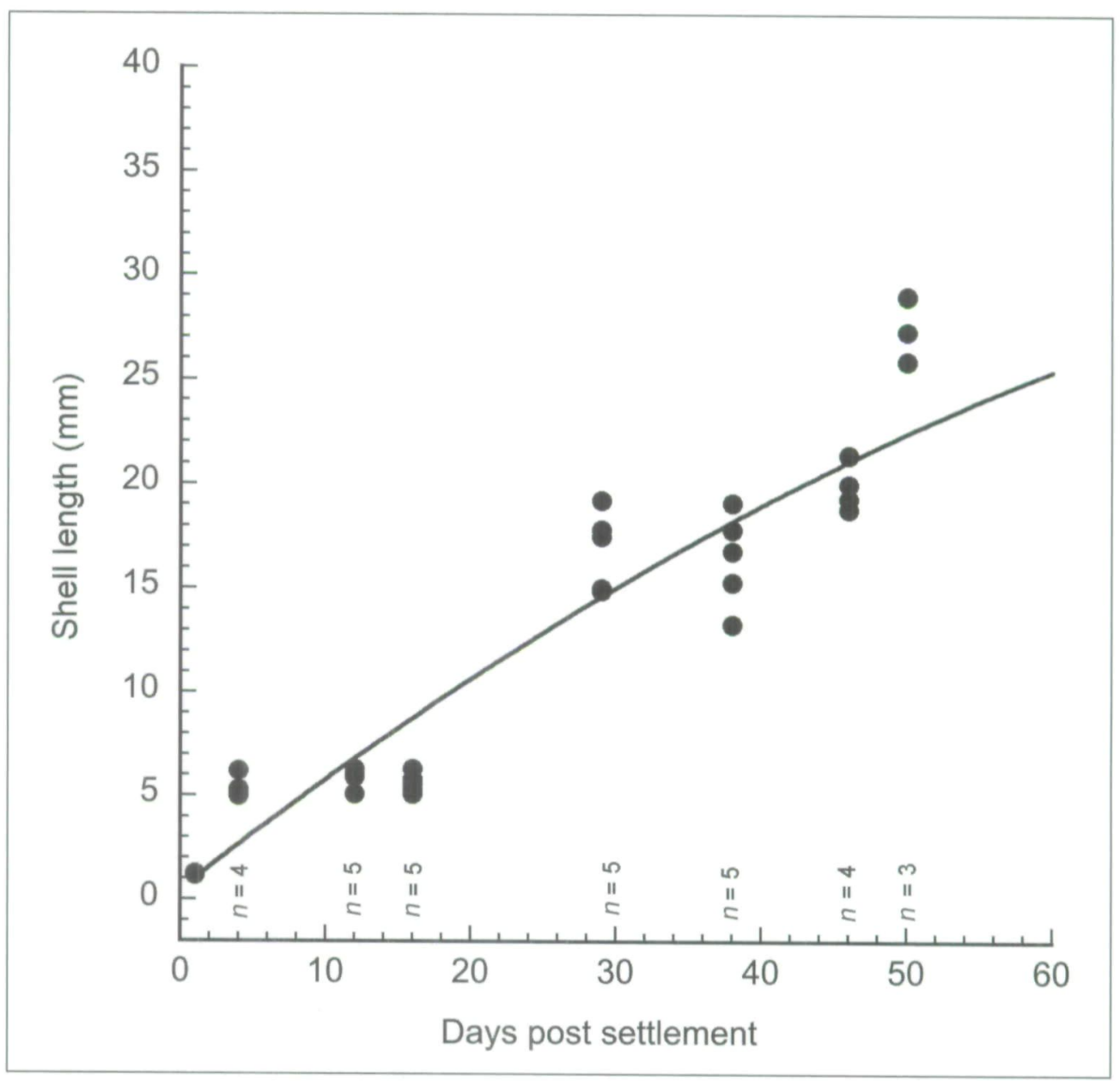

Figure 3. Shell lengths (SL, mm) with regard to number of days post-settlement (DPS) for Veined Rapa Whelks cultured in flow-through conditions at water temperatures $>20$ ${ }^{\circ} \mathrm{C}$ at the Virginia Institute of Marine Science, Gloucester Point, VA (J. Harding, unpubl. data). The fitted line has a coefficient of determination of 0.93 and the form: $\mathrm{SL}=0.45+$ $(0.56 * \mathrm{DPS})+\left(-0.0023 * \mathrm{DPS}^{2}\right)$. 
size range for rapa whelks that are within $48 \mathrm{hr}$ post settlement (Fig. 3). Previously observed turtle migration times between Chesapeake Bay and Wassaw Island, GA are on the order of several weeks to months (Plotkin and Spotila 2002, Williams and Frick 2008). Thus, the presence of these very recently settled live rapa whelks on turtles nesting in Wassaw Island, GA indicates a source population of Veined Rapa Whelks that is geographically distinct from the Chesapeake Bay. Savannah and Charleston harbors are in close proximity to Wassaw Island (Fig. 1). Both of these ports receive substantial volumes of domestic and international commercial ship traffic (Miller et al. 2007). Savannah and Charleston have suitable seasonal temperature ranges such that if rapa whelk veligers were introduced via shipping traffic they would likely be successful (Mann and Harding 2000).

It is possible that turtles encounter and swim through ballast water plumes containing live Rapana veligers that are discharged from ships arriving from the

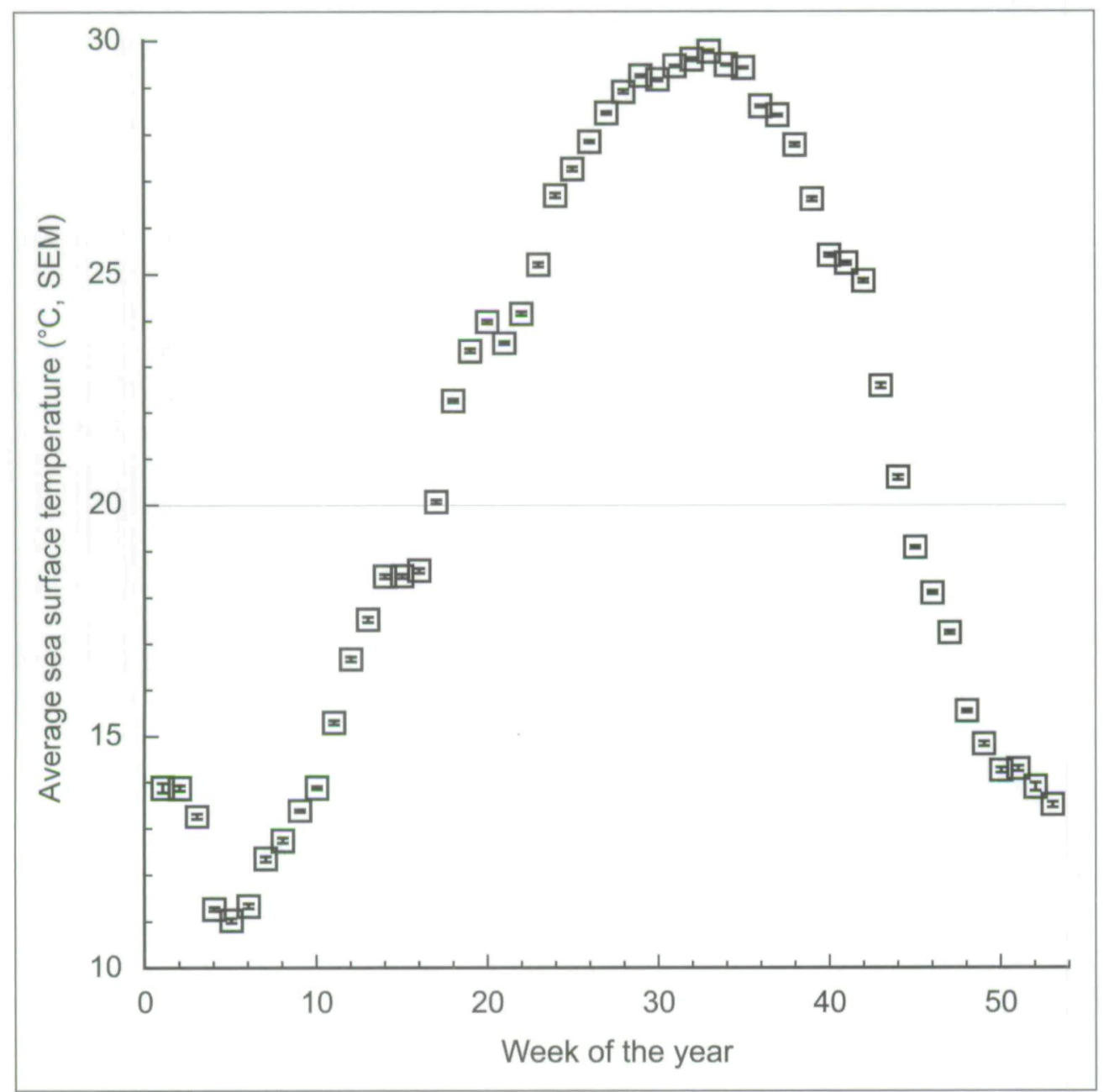

Figure 4. Average weekly sea surface temperatures recorded at Fort Pulaski near Savannah, GA from 2005 through 2009 (data are from NOAA monitoring site at Fort Pulaski in Savannah Harbor, $32.033^{\circ} \mathrm{N}, 80.902^{\circ} \mathrm{W}$ : FPKG1). The black horizontal line denotes the $20{ }^{\circ} \mathrm{C}$ threshold. 
Chesapeake Bay to either Savannah or Charleston. Ballast water is an efficient vector for the transport of invasive species (e.g., Carlton 1996, Fofonoff et al. 2003) and is likely the mechanism by which Rapana were introduced to the Chesapeake Bay from the Black Sea (Mann and Harding 2000). The US Coast Guard mandates ballast water exchange prior to entry into ports from ports outside the Exclusive Economic Zone or more than 200 nautical miles offshore (US Coast Guard 2004). The discharge of Chesapeake ballast water that was taken on between June and October, when Bay waters are warmer than $18-20{ }^{\circ} \mathrm{C}$ and rapa whelk egg capsules are present and hatching (Harding et al. 2007a, 2008), would likely introduce rapa whelk veligers to coastal waters. Survival of the veligers post-discharge would depend on water temperature, food availability, and, eventually, encounter rates with hard substrates suitable for successful settlement.

It is also possible that turtle migrations from the Chesapeake Bay to other regions have promoted the dispersal of $R$. venosa out of the Bay, and additional Veined Rapa Whelk populations have yet to be discovered. Regardless, the presence of newly settled $R$. venosa on Loggerhead Turtles in Georgia may indicate the presence of an unknown, established $R$. venosa population or the initial stage of $R$. venosa colonization in the Georgia/South Carolina region. Either way, the Loggerhead Turtle epibiotic communities commonly reported from this region (e.g., Frick et al. 1998, 2004) undoubtedly offer young whelks an optimal food source for further development. Once whelks settle upon the turtle carapace, epibiont communities present a foraging habitat with little competition but, eventually, limited food resources. The largest Wassaw rapa whelks $(\approx 25-30 \mathrm{~mm}$ SL, Table 1$)$ correspond to the shell length range $(30-40 \mathrm{~mm})$ at which rapa whelks transition from epifaunal to infaunal with corresponding changes in prey field (Harding 2003). It is likely that the relatively high profile of a rapa whelk shell $>30 \mathrm{~mm}$ SL relative to the other epibiota increases drag on the whelk, causing it to be dislodged from the turtle during swimming. Rapa whelks $<30 \mathrm{~mm}$ shell length would offer profiles similar to large barnacle tests, and the whelks would probably take advantage of the habitat heterogeneity offered by the barnacle tests.

The question remains as to whether or not migrating Loggerhead Turtles have introduced rapa whelks to habitats outside of the Chesapeake Bay in sufficient numbers to establish one or more successful breeding populations (Williamson 1996). The current observations suggest that migrating sea turtles can and do act as a vector for Veined Rapa Whelk dispersal in coastal and oceanic waters. The sources of whelk veligers and juveniles on turtles outside of the Chesapeake Bay bear further investigation. If rapa whelks can colonize turtles from the plankton and then be successfully transported to new areas to establish viable reproductive colonies, then areas ranging from Long Island Sound, NY to Mobile, AL are at risk for rapa whelk invasion and colonization.

\section{Acknowledgments}

We wish to thank Dr. Robert George D.V.M., Dr. Jacque Schuder D.V.M., William Dieffenbach, the staff and volunteers from the Virginia Aquarium Stranding Response Team, the Virginia Aquarium Foundation, and Norfolk Naval Base personnel for reporting the 
turtle to the stranding network. We also thank Kristina L. Williams, Ed Strohsahl, and Jason Fuller for their help with whelk collections on Wassaw Island. This is contribution number 3143 from the Virginia Institute of Marine Science.

\section{Literature Cited}

Bombace, G., G. Fabi, L. Fiorentini, and S. Speranza. 1994. Analysis of the efficacy of artificial reefs located in five different areas of the Adriatic Sea. Bulletin of Marine Science 55(2-3):559-580.

Burke, V.J., E.A. Standora., and S.J. Morreale. 1991. Factors affecting strandings of cold-stunned juvenile Kemp's Ridley and Loggerhead Sea Turtles in Long Island, NY. Copeia 4:1136-1138.

Carlton, J. 1996. Pattern, process, and prediction in marine invasion ecology. Biological Conservation 78:97-106.

Chung, E.Y., S.Y. Kim, and Y.G. Kim. 1993. Reproductive ecology of the Purple Shell, Rapana venosa (Gastropod: Muricidae), with special reference to the reproductive cycle, deposition of egg capsules, and hatching of larvae. Korean Journal of Malacology 9(2):1-15.

Chukchin, V. 1984. Ecology of the gastropod molluses of the Black Sea. Academy of Science USSR, Kiev. Naukova Dumka. 175 pp.

Dodd, C.K., Jr. 1988. Synopsis of the biological data on the Loggerhead Sea Turtle, Caretta caretta (Linnaeus, 1758). U.S. Fish and Wildlife Service, Washington, DC. Biological Reports 88.110 pp.

Drapkin, E. 1963. Effect of Rapana bezoar Linne' (Mollusca: Muridicae) on the Black Sea fauna. Doklady Akademii Nauk SRR 151:700-703.

Fofonoff, P., G.M. Ruiz, B. Steves, and J.T. Carlton. 2003. In ships or on ships? Mechanisms of transfer and invasion for nonnative species to the coasts of North America. Pp. 152-182, In G.M. Riuz and J.T. Carlton (Eds.). Invasive Species Vector and Management Strategies. Island Press, Washington, DC.

Frazier, J., D. Margaritoulis, K. Muldoon, C. W.Potter, J. Rosewater, C. Ruckdeschel, and S. Salas. 1985. Epizoan communities on marine turtles. I. Bivalve and gastropod mollusks. Marine Ecology 6:127-140.

Frick, M.G., K.L. Williams, and M. Robinson. 1998. Epibionts associated with nesting Loggerhead Sea Turtles (Caretta caretta) in Georgia, USA. Herpetological Review 29:211-214.

Frick, M.G., P.A. Mason, K.L. Williams, K. Andrews, and H. Gerstung. 2003. Epibionts of Hawksbill Turtles in a Caribbean nesting ground: A potentially unique association with snapping shrimp (Crustacea: Alpheidae). Marine Turtle Newsletter 99:8-11.

Frick, M.G., K.L. Williams, E.J. Markesteyn, J.B. Pfaller, and R.E. Frick. 2004. New records and observations of epibionts from Loggerhead Sea Turtles. Southeastern Naturalist 3:613-620.

Frick, M.G., J.D. Zardus, and E.A. Lazo-Wasem. 2010. A new coronuloid barnacle subfamily, genus, and species from Cheloniid sea turtles. Bulletin of the Peabody Museum of Natural History 51:169-177.

Giberto, D., C. Bremec, L. Schejter, A. Schiatriti, H. Mianzan, and H. Acha. 2006. The invasive rapa whelk Rapana venosa (Valenciennes 1846): Status and potential ecological impacts in the Rio de la Plata estuary, Argentina-Uruguay. Journal of Shellfish Research 25:919-924.

Harding, J.M. 2003. Blue Crabs Callinectes sapidus as a potential control mechanism for a non-native predatory gastropod Rapana venosa. Journal of Experimental Marine Biology and Ecology 297:161-177. 
Harding, J.M. 2006. Growth and development of Veined Rapa Whelk, Rapana venosa, veligers. Journal of Shellfish Research 25(3):941-946.

Harding, J.M., and R. Mann. 1999. Observations on the biology of the Veined Rapa Whelk, Rapana venosa (Valenciennes, 1846) in the Chesapeake Bay. Journal of Shellfish Research 18:9-18.

Harding J.M., and R. Mann 2005. Veined Rapa Whelk, Rapana venosa, range extensions in the Virginia waters of Chesapeake Bay, USA. Journal of Shellfish Research 24:381-385.

Harding, J.M., R. Mann, P. Kingsley-Smith, and D. Savini. 2007a. Comparison of predation signatures left by Atlantic Oyster Drills (Urosalpinx cinerea Say; Muricidae) and Veined Rapa Whelks (Rapana venosa Valenciennes, Muricidae) in bivalve prey. Journal of Experimental Marine Biology and Ecology 352(2007):1-11.

Harding J.M., R. Mann, and C. Ware-Kilduff. 2007b. The effects of female size on fecundity in a large marine gastropod Rapana venosa (Muricidae). Journal of Shellfish Research. 26:33-42.

Harding, J.M. R. Mann, and C. Kilduff. 2008. Influence of environmental factors and female size on reproductive output in an invasive temperate marine gastropod, Rapana venosa (Muricidae). Marine Biology 155(6):571-582.

Jaureguizar, A.J., R. Menni, C. Bremec, H. Mianzan, and C. Lasta. 2003. Fish assemblage and environmental patterns in Rio de la Plata estuary. Estuarine Coastal and Shelf Science 56(2003):921-933.

Keinath, J.A., J.A. Musick, and R.A. Byles. 1987. Aspects of the biology of Virginia's sea turtles: 1979-1986. Virginia Journal of Science 38(4):329-336.

Lezama, C., M. Lopez-Mendilaharsu., and F Scarabino. 2006. Interaction between the Green Sea Turtle (Chelonia mydas) and an alien gastropod (Rapana venosa) in Uruguay. Pp. 64-65, In M. Frick, A. Panagopoulou, A.F. Rees, and K. Williams (Compilers). 2006. Book of Abstracts. Twenty Sixth Annual Symposium on Sea Turtle Biology and Conservation. International Sea Turtle Society, Athens, Greece. 376 pp.

Lutcavage, M., and J.A. Musick. 1985. Aspects of biology of sea turtles in Virginia. Copeia 2:449-456.

Mann, R., and J.M. Harding. 2000. Invasion of the North American Atlantic coast by a large predatory Asian mollusc. Biological Invasions 2:7-22.

Mann, R., A. Occhipinti, and J.M. Harding. 2004. Alien species alert: Rapana venosa (Veined Whelk) International Council for the Exploration of the Sea Cooperative Research Report 264:1-14.

Mansfield, K.L. 2006. Sources of mortality, movements, and behavior of sea turtles in Virginai. Ph.D. Dissertation. College of William and Mary, Gloucester Point, VA.

Meylan, A.B., K.A. Bjorndal and B.J. Turner. 1983. Sea turtles nesting at Melbourne Beach, Florida 2. Post-nesting movements of Caretta caretta. Biological Conservation 26:79-90.

Miller, A.W., K. Lion, M.S. Minton, and G.M. Ruiz. 2007. Status and trends of ballast water management in the United States. Third biennial report of the National Ballast Information Clearinghouse (January 2004 to December 2005). Smithsonian Environmental Research Center, Edgewater, MD. 62 pp.

Morton, B. 1994. Prey preference and method of attack by Rapana bezoar (Gastropoda: Muricidae) from Hong Kong. Pp. 309-235, In B. Morton (Ed.). The Malacofauna of Hong Kong and Southern China III. Hong Kong University Press, Hong Kong.

Musick, J.A., and C.J. Limpus, 1997. Habitat utilization and migration in juvenile sea turtles. Pp. 137-163, In J.A. Lutz, and J.A Musick (Eds.). The Biology of Sea Turtles. CRC Press, Boca Raton, FL. 432 pp. 
National Marine Fisheries Service and US Fish and Wildlife Service (NMFS and USFWS). 2008. Recovery plan for the northwest Atlantic population of the Loggerhead Sea Turtle (Caretta caretta). Second Revision. National Marine Fisheries Service, Silver Spring, MD. 325 pp.

Norton, T.M., J.M. Keller, M. Pedan-Adams, R.D. Day, N. Stedman, A. Segars, E. Greiner, C. Harms, M. Frick, M.G. Dodd, B. Schroeder, W.G. Teas, T. Sheridan, B. Hecker, and E. Jacobson. 2008. Debilitated Loggerhead Turtle (Caretta caretta) syndrome along the southeastern US coast: Incidence, pathogenesis, and monitoring. NOAA Technical Memorandum NMFS-SEFSC-582. 36 pp. NOAA, Beaufort, NC.

Pastorino, G., P. Penchaszadeh, L. Schejter, and C. Bremec. 2000. Rapana venosa (Valenciennes 1846) (Mollusca: Muricidae): A new gastropod in south Atlantic waters. Journal of Shellfish Research 19:897-899.

Pfaller, J.B., M.G. Frick, K.A. Reich, K.L. Williams, and K.A. Bjorndal. 2008. Carapace epibionts of Loggerhead Turtles (Caretta caretta) nesting at Canaveral National Seashore. Journal of Natural History 42:1095-1102.

Plotkin, P.T., and J.R. Spotila. 2002. Post-nesting migrations of Loggerhead Turtles Caretta caretta from Georgia, USA: Conservation implications for a genetically distinct subpopulation. Oryx 36(4):396-399.

Sakai, A, F. Allendorf, J. Holt, D. Lodge, J. Molofsky, K. With, S. Baughman, R. Cabin, J. Cohen, N. Ellstrand, D. McCauley, P. O’Neil, I. Parker, J. Thompson, and S. Weller. 2001. The population biology of invasive species. Annual Review of Ecology and Systematics 32:305-332.

Savini, D., J.M. Harding, and R. Mann. 2002. Rapa whelk Rapana venosa (Valenciennes, 1846) predation rates on hard clams Mercenaria mercenaria (Linneaus, 1758). Journal of Shellfish Research 21(2):777-779.

Seney, E., and J.A. Musick. 2007. Historical diet analysis of Loggerhead Sea Turtles (Caretta caretta) in Virginia. Copeia 2007(2):478-489.

Stamper, M.A., C. Harms, S.P. Epperly, J. McNeill, and M.K. Stoskopf. 2005. Relationship between barnacle epibiotic load and hematologic parameters in Loggerhead Sea Turtles (Caretta caretta): A comparison between migratory and residential animals in Pamlico Sound, North Carolina. Journal of Zoo and Wildlife Medicine 36:635-641.

US Coast Guard. 2004. Final rule: Mandatory ballast-water management program for US waters. US Coast Guard, Washington, DC. 69 FR 44952. 28 July 2004.

Vinck, R., D. Nieweg, and H. Post. 2005. Rapana venosa (Valenciennes, 1846): A new invasive species for the Netherlands (and England?). Spirula 345:152-155.

Williams, K.L., and M.G. Frick. 2008. Tag returns from Loggerhead Turtles from Wassaw Island, Georgia. Southeastern Naturalist 7(1):165-172.

Williamson, M. 1996. Biological Invasions. Chapmann and Hall, New York, NY.

Zolotarev, V. 1996. The Black Sea ecosystem changes related to the introduction of new mollusc species. Marine Ecology 17:227-236. 
Copyright of Southeastern Naturalist is the property of Humboldt Field Research Institute and its content may not be copied or emailed to multiple sites or posted to a listserv without the copyright holder's express written permission. However, users may print, download, or email articles for individual use. 